\title{
乗船客向けAR技術を用いた船舶情報表示アプリの開発
}

\author{
吉田 南穂子 ${ }^{1}$ ・瀬田 広明 ${ }^{2} \cdot$ 三浦 宣昭 ${ }^{3} \cdot$ 中森 崇博 $^{4}$

\section{Development of Ship Information Display App for Passengers using AR Technology}

\author{
Nahoko YOSHIDA, Hiroaki SETA, Nobuaki MIURA and \\ Takahiro NAKAMORI
}

\begin{abstract}
Ferryboat's passengers often see other ships, but in many cases, they do not know what type of ship those are. In recent years, the holding rate of portable information terminals such as smart phones and tablets got higher. Also, an environment that makes it easy to acquire ship information has been prepared with the spread of AIS.

In this research, authors applied a virtual reality technology and information technology to the maritime technology fields and developed a system which displays some information of the ships and sightseeing spots displayed in the camera image.
\end{abstract}

Keywords: Information processing, Augmented Reality, Portable information terminal, Application, Automatic identification system

キーワード: 情報処理、拡張現実、携帯情報端末、アプリケーション、船舶自動識別装置

\section{1. はじめに}

伊勢志摩は参拝者 800 万人以上が訪れる伊勢 神宮など観光資源を有し、多くの観光客が来訪する。 その時、使用する交通機関にはフェリーを使用して 訪れる者もいる。その中で伊勢湾フェリー（図 1) は、風光明媚な伊勢湾口を航行し、鳥羽と伊良湖を 結ぶ国道 42 号（海上区間）を引き受けており、昭 和 39 年の航路開設以来、鳥羽・伊勢志摩地区の文 化や経済の発展に尽くしてきた。

伊勢湾フェリー乗船中の乗客に対するサービス として、音声案内による主要な観光施設の紹介があ るが、付近を往来する船舶の情報（船種・船型・船 籍など）を紹介することは難しい。しかし、乗船客

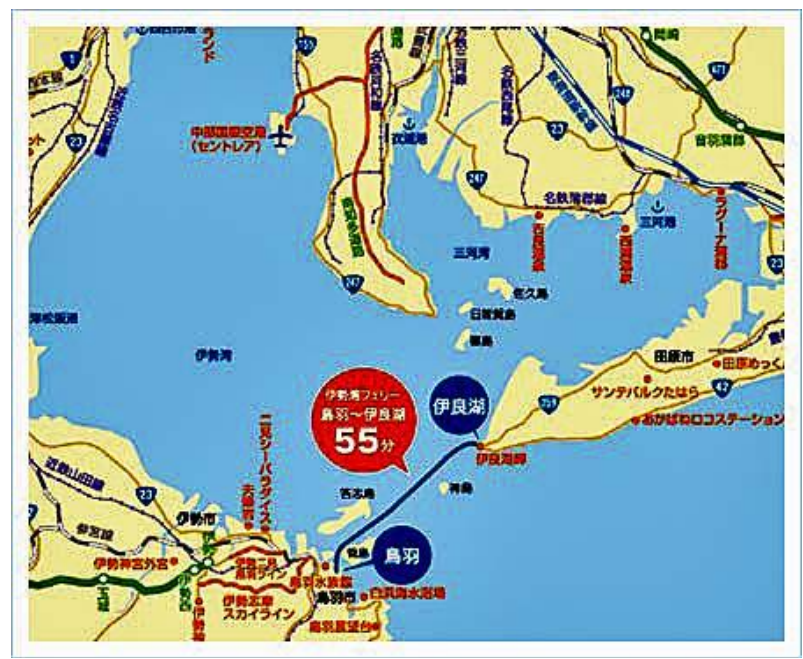

困 1 伊勢湾フェリーの航路 ${ }^{(1)}$

\footnotetext{
正会員 鳥羽商船高等専門学校 （广518-8501 三重県鳥羽市池上町 1-1） yoshida@toba-cmt. ac. jp

正会員 鳥羽商船高等専門学校

非会員＼cjkstart伊勢湾フェリー株式会社

非会員 有限会社ナカモリデザイン
} 
に船舶の情報を紹介できれば海事思想普及活動の一 助になると共に、顧客満足度も向上寸ることが考え られる。

そこで本研究では、伊勢湾フェリーだけでなく乗 船客向けに船舶の情報および観光スポットを紹介寸 る情報提供型の案内サービスを開発することを目的 とする。具体的には乗船客向けに、位置情報と船舶 運航者が有する情報を、周囲の観光情報と合わせて、 案内コンテンツとして表示するスマートフォンやタ ブレット用アプリケーションを開発し、評価を行う。

\section{AR 技術を用いた情報表示システム}

本研究で開発する乗船客向けの情報表示システ ムは、AR（Augmented Reality：拡張現実）技術を用 いる。AR 技術とは、現実空間に付加情報を表示させ、 現実世界を拡張する技術のことであり、スマートフ オンやタブレットなどの情報端末（以降、情報端末 と呼ぶ）に搭載されているカメラからの映像情報に 各種情報をリアルタイムで重畳表示させて表現する ものである(2)。

船舶の動静情報（以降、AIS 情報と呼ぶ）は、AIS (Automatically Identification System: 船舶自動 識別装置) 受信機から得ている。AIS は、自船の位 置や速力などの情報を周囲に知らせる航海計器であ る。AIS 情報を利用すれば、船上や陸上で容易に情 報の取得することも可能であり、航海士向けのスマ 一トフォンの利用も行われている ${ }^{(3)}$ 。そこで、AIS で得られたデータは無線 LANを介して配信し、乗船 客が持つ市販の情報端末で船舶情報として、さらに 観光情報も同時に表示寸るアプリケーション(以降、

「本アプリ」と呼ぶ）を新たに開発した。なお、航 路周辺の観光情報は、アプリ内に予めデータベース を構築し、そこから入手し画面に表示する方法をと した。

\section{1 情報表示アプリの設計}

情報端末を持つ多くの乗船客や今後の発展性を

\section{表 1 アプリの動作対象機種および開発環境}

\begin{tabular}{|l|l|l|}
\hline \multicolumn{1}{|c|}{ 種類 } & \multicolumn{1}{|c|}{ 対象 OS } & \multicolumn{1}{|c|}{ 開発環境 } \\
\hline $\begin{array}{l}\text { iPhone, } \\
\text { iPad }\end{array}$ & $\begin{array}{l}\text { i0S 10.0 以上で GPS } \\
\text { 受信機内蔵のモデル }\end{array}$ & XCode $(\mathrm{C}++)$ \\
\hline Android & $\begin{array}{l}\text { Abdroid5.0 以上 } \\
\text { GPS 受信機内蔵のモ } \\
\text { デル }\end{array}$ & $\begin{array}{c}\text { Android studio } \\
\text { (JAVA) }\end{array}$ \\
\hline
\end{tabular}

考慮して本アプリの動作対象機種は GPS 機能が内蔵 されている iPhone、iPad およびAndroid（表 1 )で、 開発環境はそれぞれ公式のアプリ開発ツールである XCode およびAndroid Studio である。同時に開発時 には AR 技術を利用するため、各端末ではカメラと位 置情報の機能を本アプリで利用することを許可する 必要ある。

アプリ内での処理としては次の (1)〜 (4)の順で ある。

（1）AIS 情報を受信後、AIS 情報をデコードする

（2）（1）の AIS 情報が既知の船舶からの AIS 情報か否 かを判定し保持または上書きする

（3）保持する全ての AIS 情報を情報端末に投影され ている画面内に表示するべきか否かを判定する

（4）表示と判定した場合は、アプリ画面上での船ア イコンの位置を計算し表示する

伊勢湾フェリーの場合、1 日 100 隻程度の AIS 搭 載船が伊勢湾にいるため、航海中の約 55 分で最大 100 隻程度の AIS 情報を処理する必要があるが、実 際には端末が処理するAIS 情報は 5,6 隻程度である。 情報表示の速さはアプリを動作させている端末性能 に依存しているため、性能の遅い端末は早い端末と 比較し、アプリ内で(1)から (4)を順に処理すると長 い待機時間が発生する。そのため、複数の非同期処 理を実装することや、AIS 情報を保持する配列を複 数パターン作成しデバックを行い最も効率的な配列 方法を採用することでアプリ全体は最適に内部処理 ができるようにした。同時に端末で表示されるカメ ラ画像と比較して過去データである AIS 情報との差 異を目立たせにくくするよう工夫した。

\section{2 情報表示画面の構成}

一般的な乗船客が直感的に操作できるアプリと するため、本アプリは情報端末内蔵のカメラを利用

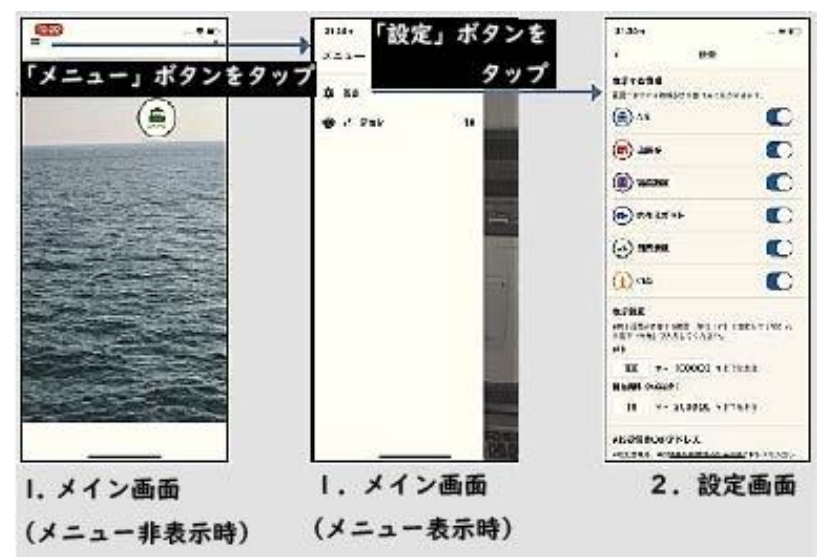

図 2 各画面の構成 
して、実在する風景に AIS 情報および観光情報を重 畳表示する。画面表示されている風景内にAIS を有 する船舶や観光情報データに該当する観光スポット が含まれている場合は、AIS 搭載船および観光スポ ットの周辺にアイコンが表示される。利用者はそれ らのアイコンをタップすることで対象船舶の動静情 報や対象施設の観光情報を閲覧でき、各種情報を得 ることができる。

図 2 は本アプリの画面構成を示している。「メイ ン画面」は、カメラの映像および各種情報、または 設定メニューを表示する画面であり、「設定画面」は AIS 情報を受信に関する設定や情報の表示に関する 設定を行う画面である。

\section{2.1 メイン画面の構成}

図 3 はメイン画面の構成要素を示しており、6 層 の画面から形成されている。最下層のカメラの層は、 端末のカメラ映像を常に表示しており、端末を動か すと、動かした先の映像が表示される。また、ピン チイン・ピンチアウトにも対応することが可能であ る。2 層目のアイコンの層は、端末の方位角や傾き に応じて各種アイコンを配置している。カメラの層 に写っている風景に AIS 情報を発信する船または観

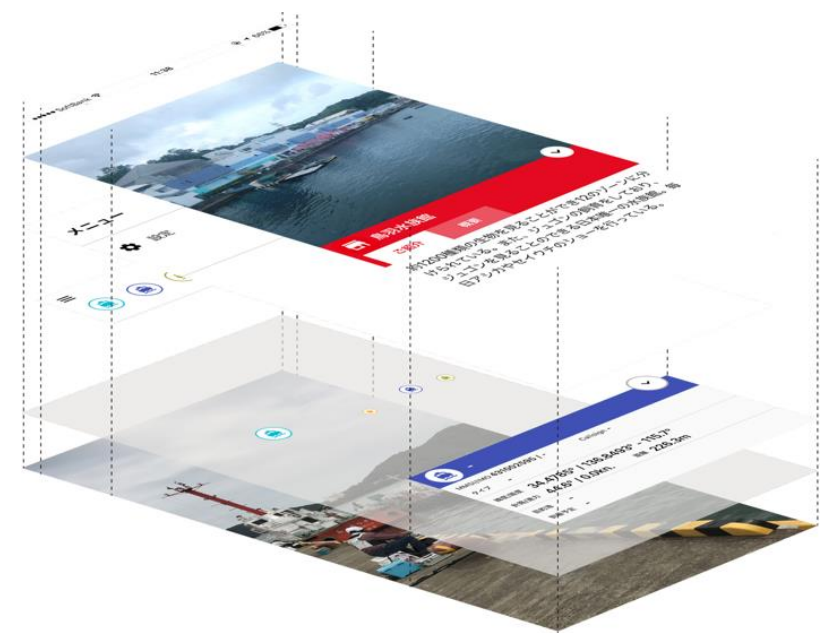

図 3 メイン画面の構成要素

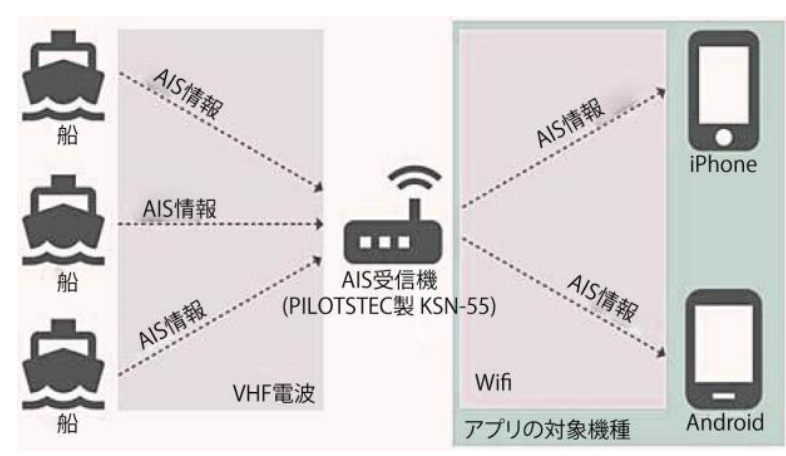

図 4 船舶間通信と情報端末との通信
光情報が含まれている施設が存在する場合は、その 付近にAIS アイコンまたは観光情報アイコンを表示 する。また、情報端末と船舶または対象施設との距 離が近いほどアイコンを大きく表示し、直感的に対 象物との距離がわかるように工夫した。3 層目は、 AIS 情報および端末の情報を表示する層であり、AIS 情報を取得した船舶のアイコンをタップした際に、 対象船舶の各種情報を画面下部に表示する。4 層目 はAIS 情報を取得した船舶のアイコンを画面上部に 整理して表示寸る層であり、一覧表示の要否の選択 が可能である。 5 層目はメニュー画面の表示切り替 えの層である。最上層の 6 層目は観光情報の層とな っている。

\section{2.2 船舶情報表示画面の構成}

旅客船では様々な総卜ン数の船舶が運航されて おり、AIS 非搭載の船舶や AIS 搭載船であっても AIS 情報を容易に外部出力寸る端子がない船舶がある。 そのため、船舶の動静情報は多くの旅客船での実装 の利便性を考え NMEA センテンス ${ }^{(4)}$ 既設 AIS から情 報を得ず、図 4 に示すようにAIS 受信機 (PILOTSTEC 製 KSN-55)をアプリ専用で既設 AIS とは別に用意し、 情報を得ることとした。換言すれば、既設の AIS 受 信システムの大掛かりな配線工事を要さず、船舶運 航に支障を来寸恐れが無くなる。アプリ上では、こ の情報を受信、デコードし、実在する風景に船舶の アイコンを表示するとともに船舶の情報を重畳表示 させる必要がある。

図 5 は本研究で製作したアプリの表示画面を示し ている。同図の左図は画角を広く取った時のもので あり、右図は対象船舶を拡大表示（ピンチアウト） した時のものである。表示映像の拡大に伴いアイコ ンも拡大表示される。画面内にある船のアイコンを タップすると、画面下部に当該船舶の AIS 情報を表 示することが可能となる。

図 6 はその一例を示しており、表示内容は、船名、 船種、位置 (緯度・経度)、針路、速力、対象船舶ま での方位と距離、目的地などである。また、画面下 部にAIS 情報が表示されている時に他の船アイコン

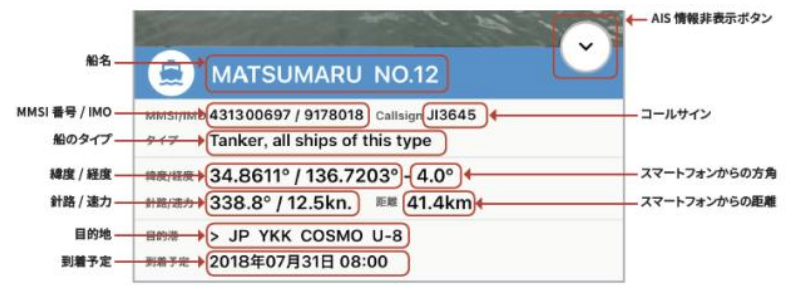

図 5 アプリの表示画面 
をタップした場合は、当該船舶の AIS 情報に置き変 わる。アプリ上に表示寸る情報は船舶からの取得で きる情報の他、海上では距離感が把握しがたいため 当該船舶までの距離と方位を示している。これらの 機能については、乗船客だけでなく、乗組員が船橋 以外で周囲の船舶を知るための道具として活用を期 待できる。

\section{2.3 観光情報表示画面の構成}

図 7 に示すように、観光情報は「紹介」および「概 要」の 2 種類の情報表示があり、タブをタップする ことで表示する情報を切り替えることが可能である。 観光情報は名称、紹介文、アクセス方法や連絡先な どの情報が表示されている。また、観光情報をタイ プ別に店舗等、宿泊施設、釣りスポット、自然景観、 灯台の 5 つに分類し、それぞれに対応したアイコン

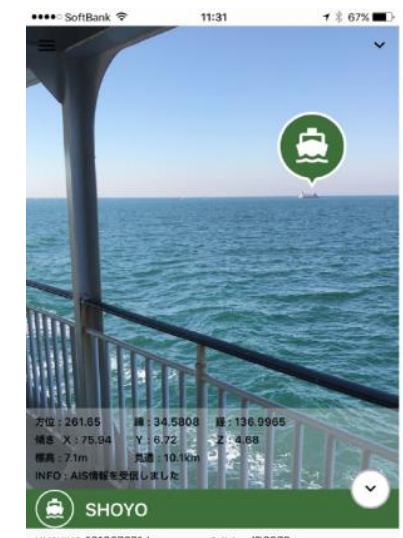

Musinmo A31007277\% C Cargo, all ships of this type

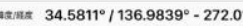
Hatas $310.8^{\circ} / 11.1 \mathrm{kn}$. $=1150.7 \mathrm{~m}$ 1his $>$ JPP NGO B3 2017年12月22日 14:30

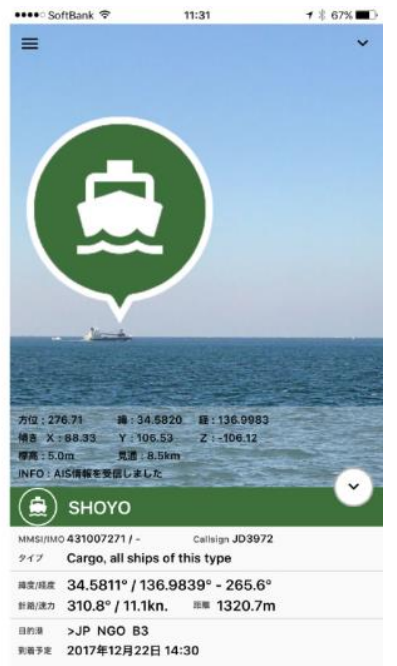

図 6 AIS 情報の表示内容

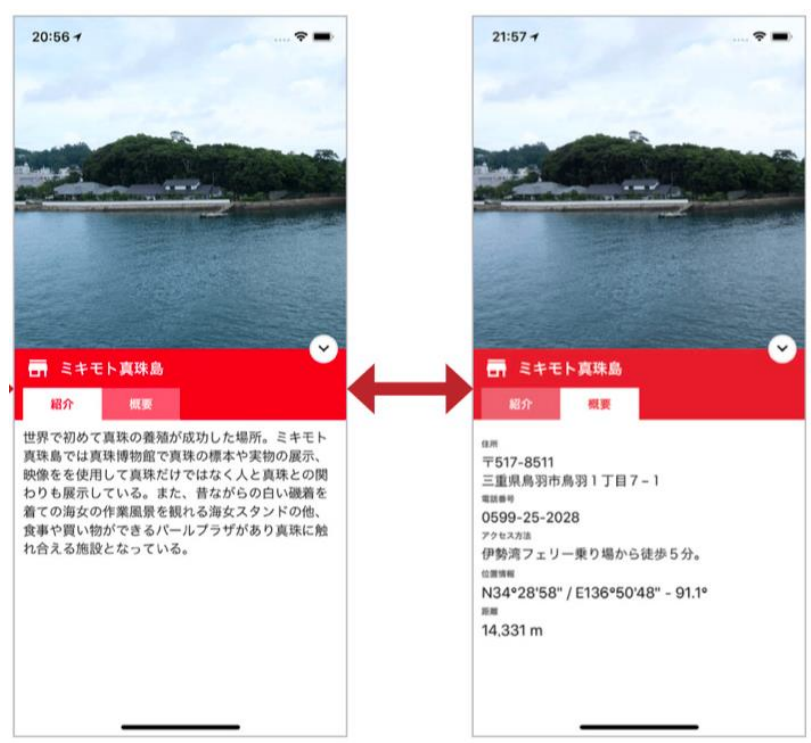

図 7 観光情報の表示例（タブで表示内容を切替）

\section{を表示している。}

\section{2.4 設定画面の構成}

図 8 に示寸画面はアプリの各種設定を行う画面で ある。AIS 情報および観光情報（店舗等、宿泊施設 など）を種類ごとに選択することができ、選択され たアイコンがメイン画面に表示される。AIS 受信機 とアプリ間はTCP接続であり本機能は IPアドレスお よび TCP ポート番号の変更を可能とし、今後の拡張 性に配慮した。

また、伊勢志摩地区は大型客船や外国人観光客の 誘致に力を注いでいる。そこで、本アプリも外国語 での対応が不可欠との考えから、「日本語」表示と

「英語」表示の言語設定機能を組込んだ。情報端末 の言語設定で「日本語」を指定していると「日本語」 表示になり、日本語以外の言語を指定していると「英 語」表示となる。

\section{3 動作確認}

本校の練習船「鳥羽丸」を用いて開発したアプリ の動作確認を実施した。池の浦から名古屋港までの 航海中（約 3 時間 30 分）に、本アプリをインストー ルした情報端末を乗船している学生が使用し続けた 結果、iPad、Android 共に問題が無いことを確認し た。なお、この間に「鳥羽丸」（空中線高さ $15 \mathrm{~m}$ ）が 受信したAIS 搭載船の隻数は約 20 隻であった。片道 1 時間弱の伊勢湾フェリーでの使用も情報端末の処 理能力や OS による違いが問題になることは無いと

\begin{tabular}{|c|c|}
\hline 21:301 & 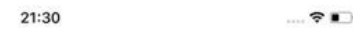 \\
\hline 蚛定 & $<$ 杸定 \\
\hline 表示する情辂 & 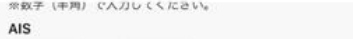 \\
\hline 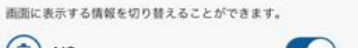 & $100 \mathrm{~m}$ - 100000 mまをを表示 \\
\hline (스 AIS & 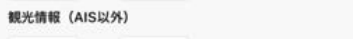 \\
\hline () 店锤等 & $10 \quad \mathrm{~m} \sim 300000 \mathrm{~m}$ まで表示 \\
\hline 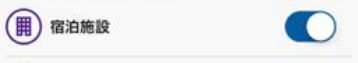 & 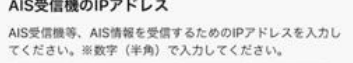 \\
\hline (4) 的ロスホット & $192 \cdot 168 \cdot 11 \cdot 1$ \\
\hline (4) 自然景镍 & 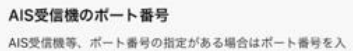 \\
\hline (1) 灯台 & 8888 \\
\hline 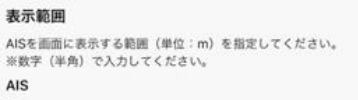 & 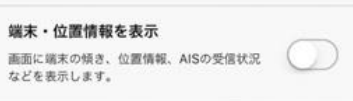 \\
\hline 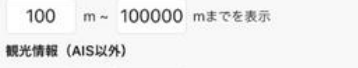 & 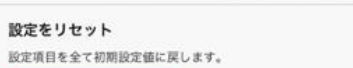 \\
\hline $10 \mathrm{~m}$ ～ $300000 \mathrm{~m}$ をを袁示 & 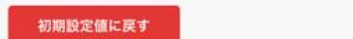 \\
\hline
\end{tabular}

言える。 


\section{3. アプリの評価}

試作したアプリの操作性や使用感を調査するた め伊勢湾フェリーの乗船客に対してアンケート調査 を実施した。実施時期は第 1 期として 2018 年 2 月 3 日（土）、4日（日）の 2 日間、第 2 期は同年 12 月 1 日（土）、3 日（月）、9 日（日）の 3 日間で行い、 それぞれ鳥羽港〜伊良湖港間を 2 往復ずつ、計 20 便で実施した。調查方法は予めアプリがインストー ルされた情報端末 (アップル社製 iPhone 2 台および iPad 5 台）を乗船客に貸し出し、数分間使用した後 にアンケート用紙に記入する形式とし、第 1 期は 91 組、第 2 期は 103 組の乗船客から回答を得た。図 9 はアプリ使用中の様子を表している。

\section{1 情報表示アプリの調査対象者}

第 1 期での調查 91 件の回答者の属性（性別、年 齢）を図 10 と図 11 に示す。なお、第 2 期での調查 結果もほぼ同様であった。また、普段使用している 情報端末を調査した結果、iPhone は $74 \% \rightarrow 52 \%$ 、 Android が 12\% ↔39\% と調查時期により大きな違いが 見受けられたが、本アプリは $90 \%$ 以上の乗船客の情 報端末に対応していることがわかった。

\section{2 アプリの操作性、使用感に関する結果}

使用感について、他船が見える空際の席に座って いる乗客に対して情報端末を手渡し、5 分程度使用 してもらった後、本アプリの操作性、使用感に関す る 7 の設問に対してそれぞれ 5 段階評価で回答する 形式を取り、また意見記入欄を設けてその他の意見 や感想の記入を依頼した。

図 12 は第 1 期の各設問とそれぞれの結果を示し ている。第 2 期も同様の内容で調查した結果、図 12

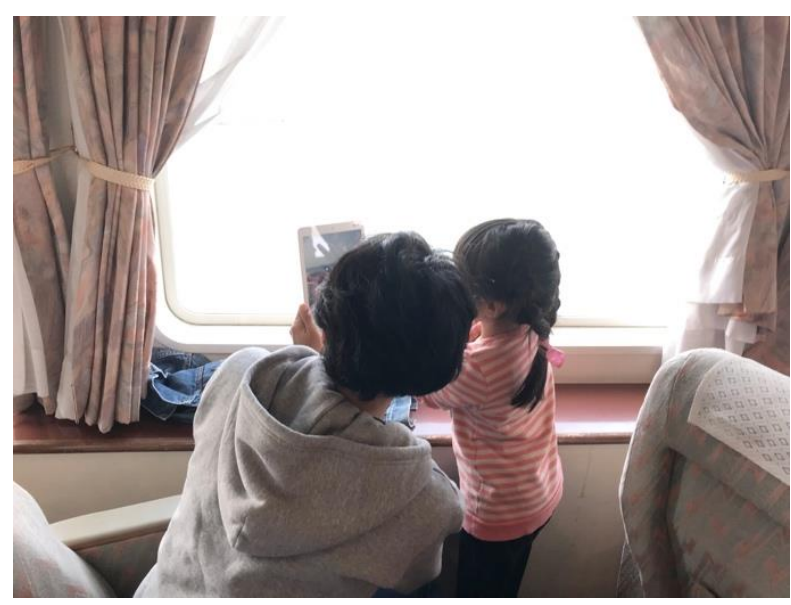

図 9 開発したアプリを使用中の乗船客
と大差ない結果となり、概ねアプリに対して肯定的 な意見を得ることができた。なお、意見記入欄に記 載されていた意見概要は以下の通りであった。

- 表示して欲しい情報

> 画面をタップしなくても名前ぐらいは表 示してほしい。

> 島の特産物・島の概要、情報がほしい。

> タップすると船の画像がでてきたら面白 い。

$>$ 飲食店の情報や天候等もあれば嬉しい。

- 良かった点や印象に残った点

> 位置を合わせるだけで情報が得られるの が嬉しい。

$>$ 操作が簡単だった。

> 釣り好きならいいと思う。漁船なども認識

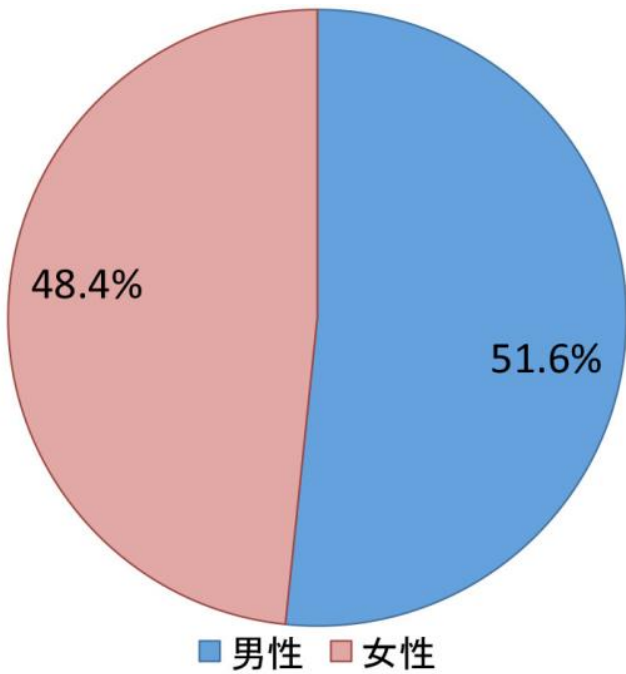

図 10 回答者の性別

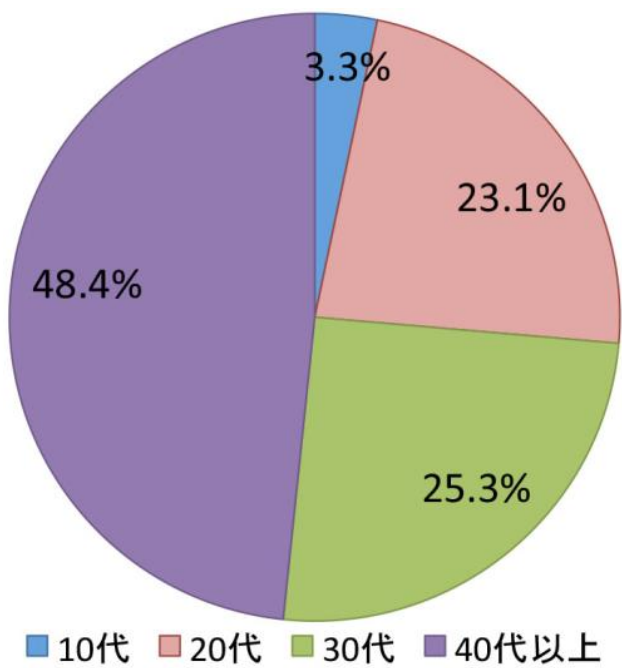

図 11 回答者の年齢 


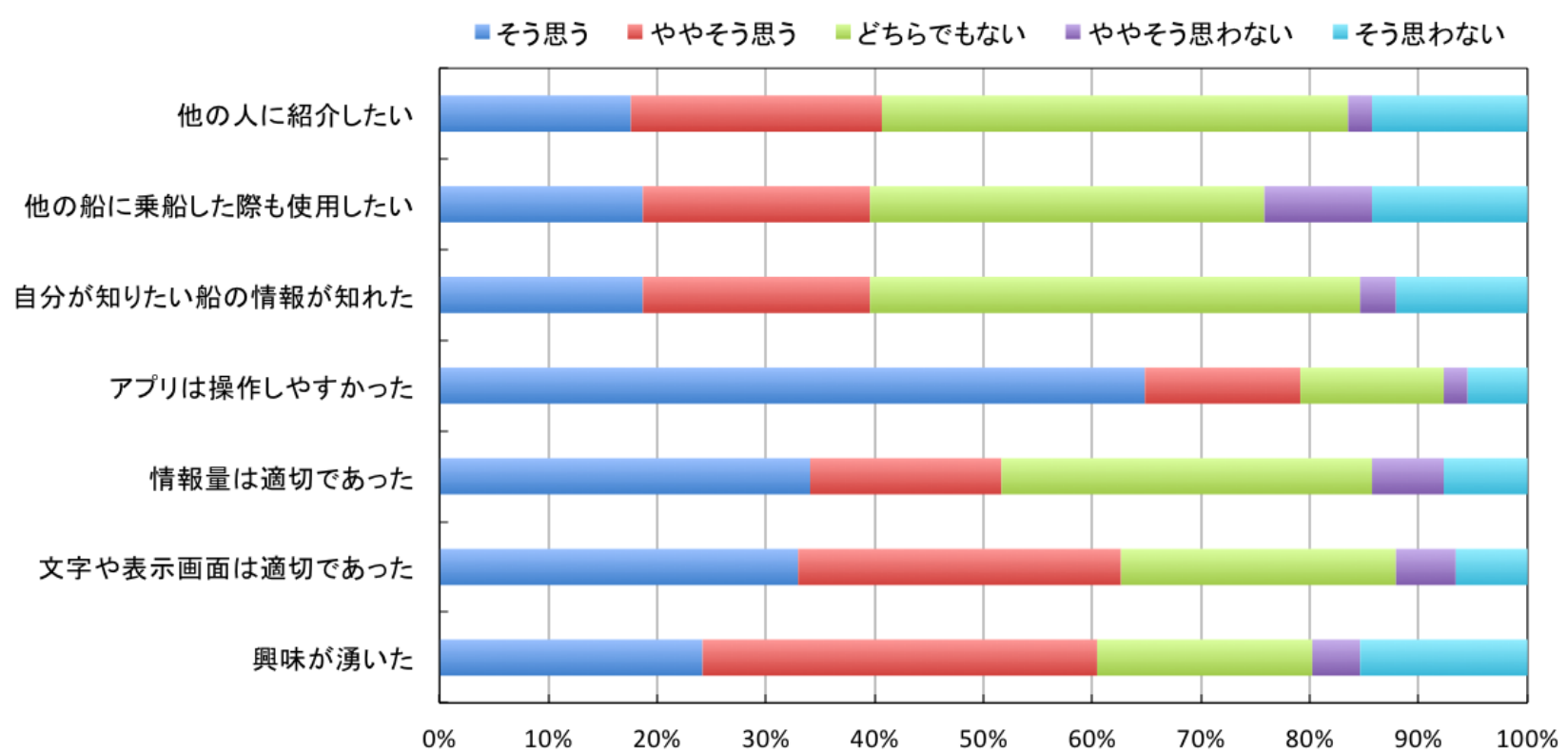

図 12 アプリの操作性、使用感に関するアンケート結果（第 1 期）

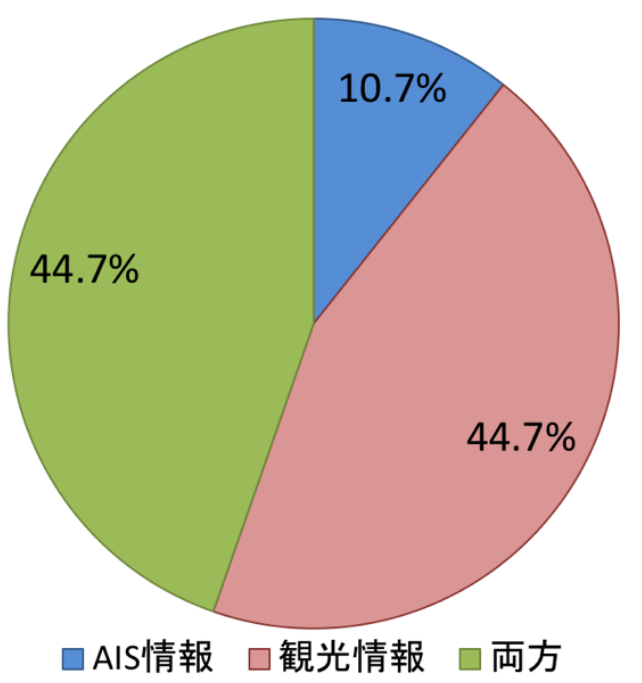

困 13 本アプリで興味を得た情報

できればいい。

$>$ 軍事的に悪用されないのかが心配。

> アイコンで建物が見えない。矢印にしてみ ては。

- その他

> 海だけでもなく、他に応用できるのでは。

> クーポンなどあればダウンロードしたい。

> 他の船でも使用できるならダウンロード する。

> 年配の方向けにもう少し簡単な操作にで きると良い。

\section{3 興味をもった情報}

本アプリで提供する情報は船舶に関する情報と 観光スポットに関する情報である。図 13 には、どち らの情報に興味を持ったかの調査結果を示す。

船の情報が可視化提供されることで乗船客の興 味を引くことができるという意見があり、本研究の 目的が果たせたとも言えるが、そもそも船そのもの に興味がない場合には、本システムの利用によって すべての人への啓発は難しいことが分かった。

印象に残った点で回答された”軍事的に悪用さ れないか心配”といった声については、本システム で使用する AIS 情報は広く販売されている AIS 受信 機で得られる情報であり軍事機密情報に該当しない。 船舶運航に支障がないよう既存の運航用 AIS 受信機 と別の本アプリ用 AIS 受信機を設けることで、仮に 本アプリの情報を改変して接続端末で情報を受信し た場合でも船舶運航用のシステムと安全上問題ない よう設計している。本システムへの接続端末を制限 する(5)することでもいたずらや悪用について防止対 応可能である。

\section{4. むすび}

本研究では、情報端末を利用してフェリーの乗船 客に対して伊良湖水道周辺を航行する船舶の情報お よび乗船客の意見にあった地名・島名・灯台といっ たスポット名など地物情報を提示するシステムを開 発し評価を行った。開発した情報端末用のアプリは、 AR 技術と既知の技術である AIS 情報を融合させる事 
により、乗船客向けの利用を促すことが可能である ことが確認できた。なお、乗船客へのアンケート調 查の結果から、作成したアプリに対して概衩満足の いく結果となっていることが伺えた。また、乗船客 の意見にあった地名・島名・灯台といったスポット 名など地物情報を表示させる機能を盛り込んだこと で、博物館などで利用されている AR のように、周辺 の船舶や観光情報の通り過ぎを防止でき ${ }^{(6)}$ 、本研究 では鳥羽・伊勢志摩地区の観光客誘致活動に繋がる ようなシステムが構築できた。

なお、本研究で開発したスマホ・タブレット用ア プリは無料で配布しているほか、技術的には乗船客 だけで無く操船者に対する情報支援機器としてAIS だけではなくレーダで捉えた目標を表示させる ${ }^{(5)}$ ど簡便に発展させることが可能なので、今後も関係 機関と協議しながら開発を進めたいと考えている。

\section{謝辞}

乗船中にアンケート調查にご協力頂いた皆さん に感謝申し上げます。なお、本研究は三重県産業支 援センターの助成を受けて実施されたものである。

\section{参考文献}

（1）伊勢湾フェリー：航路アクセス, https://www. isewanferry. co. jp/publics/ind ex/20/, 2019. 4

（2）原英樹 : デジタル革新の加速に向けた顧客体験 価值向上への AR/VR/MR 活用の取り組み, 画像 ラボ 28(7), pp. 72-81, 2017.7.

（3）鈴木治, 竹本孝弘, 添田忍, 山下久雄 : データ 入出力端子としてのパイロットポートの活用、 日本航海学会論文集 124 号, pp. 95-101, 2011.

(4) NMEA0183 Standard for Interfacing Marine Electronic Devices Version 3.01, pp. 81-87, National Marine Electronics Association (2002).

（5）瀬田広明, 鈴木治, 鈴木秀司, 天野宏 : AIS と ARPA 情報を併用した海上交通観測手法の開発、 日本航海学会論文集, 第 119 号, 27-33, 2008.

（6）神保英, 安斉賢三, 齋藤佑樹, 中村雅子 : 博物 館での学習における拡張現実 (AR) 技術の可能 性、東京都市大学横浜キャンパス情報メディア ジャーナル，第 15 号 (2014).

（7）鈴木治：船陸間通信の現状と問題点， RF ワー ルド, No. 21, CQ 出版社 (2012). 